\title{
Chert raw materials and artefacts from NE Bulgaria: A combined petrographic and LA-ICP-MS study
}

\author{
Polina Andreeva ${ }^{1}$, Elitsa Stefanova ${ }^{1}$, Maria Gurova ${ }^{2}$ \\ 1. Geological Institute, Bulgarian Academy of Sciences, 24 Acad. G. Bonchev Str., Sofia, Bulgaria. \\ Email: Andreeva: poly_a@abv.bg; Stefanova: elitsa.s@gmail.com \\ 2. National Institute of Archaeology and Museum, Bulgarian Academy of Sciences (NIAM-BAS), 2 Saborna \\ Str., 1000 Sofia, Bulgaria. Email: gurovam@yahoo.fr
}

\begin{abstract}
:
In the present study two analytical methods are applied to characterize chert artefacts and raw materials from northeastern Bulgaria (Ludogorie region): petrographic observation and laser ablation inductively coupled plasma mass spectrometry). Archaeological samples from 12 Chalcolithic sites from Bulgaria are analyzed as well as raw material from 6 outcrops in northeastern Bulgaria are identified and documented during a survey in 2012 when many raw material samples were collected. The chert raw material mostly occurs in various Quaternary secondary deposits, originating from destruction and disintegration of the Lower Cretaceous (Aptian) limestones in the area. The paper is aimed at tracing the provenance of the artefacts based on their petrographic characteristics and geochemical composition. The archaeological evidence shows a wide distribution of the Ludogorie chert throughout the country.

On the basis of micropetrographic observations, Gurova and Nachev (2008) described two main chert types (Ravno and Kriva Reka). Our petrographic study confirmed the previous results and an additional chert type was distinguished, originating from primary and secondary deposits (quarries in Koprivetz and Krasen villages) and is represented by silicified limestones (bioclastic-peloidal packstones or grainstones). It is noteworthy that the first two types of chert were largely used for prehistoric artefact manufacturing while the last one is not attested among studied assemblages at all.
\end{abstract}

Keywords: Chalcolithic; northeastern Bulgaria; Ludogorie; Ravno; Kriva Reka; petrogpahy; LA-ICPMS; super-blades; workshops

\section{Introduction and archaeological background}

The present study is focused on the prehistoric chert raw material originating from northeastern Bulgaria (Ludogorie region). The abundant and high quality deposits of siliceous rock in this part of the country, often referred to as Dobrudzha, has been the focus of archaeogeological studies for decades. The first scholar to formulate and highlight the importance of a systematic approach to the chert raw material in the context of intensified archaeological research in prehistory was Kancho Kanchev in his publication on problems and purposes of chert studies (Kanchev 1978). His surveys, carried out with the

Published by the School of History, Classics and Archaeology, University of Edinburgh ISSN: 2055-0472. URL: http://journals.ed.ac.uk/lithicstudies/

This work is licensed under a Creative Commons Attribution 2.5 UK: Scotland License. 
sedimentologist I. Nachev, led to the identification of 224 raw material outcrops in Bulgaria. The biggest concentration of chert sources occurs in three districts in north Bulgaria: Razgrad - 32 outcrops, Russe - 27 and Pleven - 24 (Kanchev 1978: 87). A particular study was devoted to the numerous and abundant chert deposits in northeastern Bulgaria, which were primarily embedded in Lower Cretaceous (Aptian) limestones that were subsequently disintegrated and redeposited as Quaternary (secondary) placers with rounded chert concretions (Nachev, Kanchev 1984). In 1988 an instructive study was published about the siliceous rocks in Bulgaria regarding the correlation of their geographic, geotectonic and stratigraphic distribution, as well as their mineral and chemical composition, diagenesis and evolution. The authors, Ivan Nachev and Chavdar Nachev, both geologists, have been deeply involved in the research of rocks as raw material for prehistoric assemblages used by human populations and commonly referred to by archaeologists as 'chert' assemblages (Nachev \& Nachev 1988). More recently, C. Nachev published a paper illustrating the characteristics and particular features of the four main geologically distinguished types of chert concretions on the basis of their comparative analysis (Gurova, Nachev 2008; Nachev 2009) (Figure 1). As described by C. Nachev, the silica concretions of Ludogorie (or Dobrudzha) chert were hosted in Lower Cretaceous (Aptian) micrite limestones with pale grey colour and are characterised by a white silica-carbonate cortex. The primary sources gave material for numerous secondary (placer) deposits with an eluvium-proluvium character. They are located mainly in the Ludogorie plateau (on the hills), hosted in soft sandy-carbonated masses (Gurova, Nachev 2008, 33; Nachev 2009). The Ludogorie chert has two microscopically distinct types: Ravno type (in the northern part of the region) and Kriva Reka type (in the southern part). In relation with its petrographic characteristics C. Nachev describes Ludogorie chert as the highest quality chert raw material in Bulgaria (and on a broader scale of southeastern Europe and Asia Minor) with large scale distribution and use in prehistoric chert assemblages (Nachev 2009, 11-12).

A significant number of studies have also been done on the prehistoric (Chalcolithic) chert assemblages from northeastern Bulgaria by the Russian specialist, Natalia Skakun, French specialist, Laurence Manolakakis (Manolakaksi 2005, Skakun 2006). Both scholars have concluded that the huge amount of the chert artefacts from northeastern Bulgarian tells (Goliamo Delchevo, Durankulak, Vinitsa, Smiadovo and Sava) and cemeteries (Varna, Durankulak) are made of Ludogorie (Dobrudza) chert. The same conclusion was reached by one of the authors of the present paper (Gurova 2001b) on the basis of investigations of Chalcolithic chert assemblages from settlements which belong to different cultures (Sava, Polianitsa, Varna) and to the of Kodžadermen-Gumelniţa-Karanovo VI cultural complex.

Both types of Ludogorie chert mentioned by $\mathrm{C}$. Nachev possess favourable properties for lamellar (blade) production that determined its use for large-scale subsistence and household activities during the Chalcolithic period as revealed by studies of sites such as Karanovo, Drama-Merdzumekja, Varhari, Burgas, Karnobat, Kosharna, Bazovets, Ivanovo, Smiadovo, and Targovishte-Garata (Gurova 2005, 2010, $2011 \mathrm{a}$, b) (Figures 2 and 3). As for the most sophisticated knapping techniques (lever pressure) and the production of extra-long blades for ritual purposes in the mortuary domain (Varna and Durankulak cemeteries) and for hoard deposits (Tell Smiadovo), undoubtedly the Ravno type of chert was used (Figures 4 and 5).

In spite of the widely acknowledged quality and the broad distribution of the Ludogorie cherts, information about raw material extraction and supply in prehistory is still rather scarce. As well, it is still debatable as to how early in prehistory the exploitation of Ludogorie chert took place. 


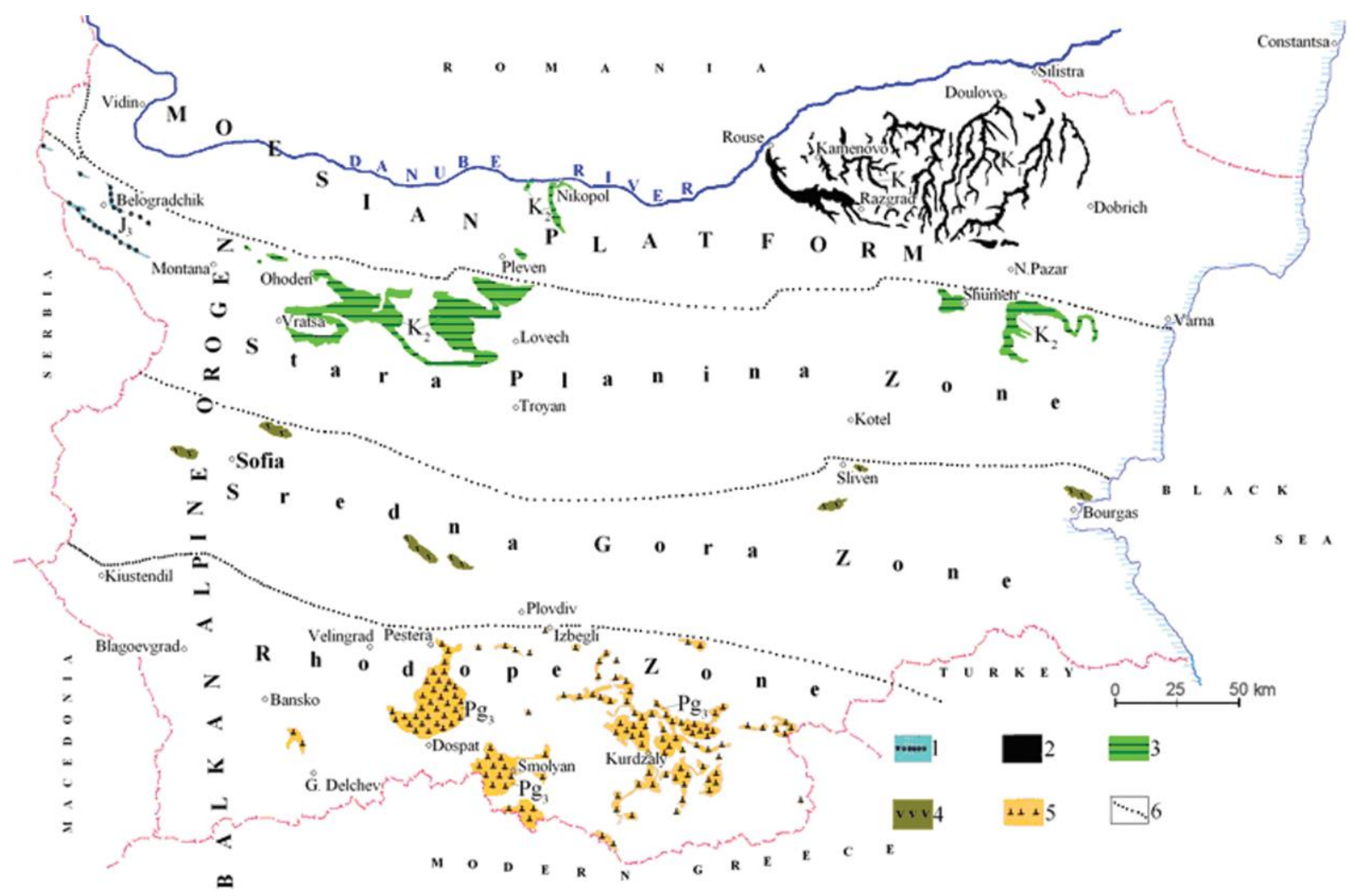

Figure 1. Geological map of the main types of flint-bearing rocks in Bulgaria: 1. Upper Jurassic limestones with siliceous concretions (J3); 2. Low Cretaceous (Aptian) limestones with siliceous concretions (K1); 3. Upper Cretaceous chalk and chalk-like limestones with siliceous concretions (K2); 4. Upper Cretaceous volcanogenous rocks with chalcedony veins in Sredna Gora Zone; 5. Oligocene volcanogenous rocks with chalcedony veins in Rhodope Zone (Pg3); 6. Boundary between tectonic zones (based on Gurova \& Nachev 2008, fig. 5).

Regarding raw material procurement and the first stage of chert production, Manolakakis' prospections and trench excavations in the Razgrad area allowed her to identify a concentration of archaeological sites on the Sakaralan plateau. The most significant accumulation of chert material indicating workshops has been localized around Ravno village with three distinct sites (Ravno 1-3) (Manolakakis 2011, 229). Another workshop for chert production with evidence of long blade removal using indirect percussion and the lever pressure technique has been identified at the Tell of Kamenovo in close proximity to the excellent quality, large chert nodule outcrops of Ravno 3 (Manolakakis 2006, 11; 2011, 233). Advancement in this field was made recently through the systematic surveys in the Razgrad district area made by Mateva. She describes the secondary chert placers as being easy for access and nodule extraction from the soft loess layers. Several new workshops have been identified near the villages Ravno, Kamenovo and Kriva Reka, and as well in the locality Chakmaka (near Isperih), (Mateva 2010, 174). The Kriva Reka raw material is presented as significant amount of secondary chert deposits on the hill named Chakmaklaka (near the village). The earliest evidence of exploitation of the deposits dates back to the Chalcolithic (although it may have been exploited even earlier, further evidence is required to support the idea of exploitation prior to the Chalcolithic) and has continue up until the mid-20th century. The chert from Kriva Reka was certainly used for different purposes, but the most remarkable specialization of the local chert knappers consisted of the manufacture of threshing sledge (tribula) inserts which had a wide distribution throughout the country (for more on this subject, see Gurova 2011c) 

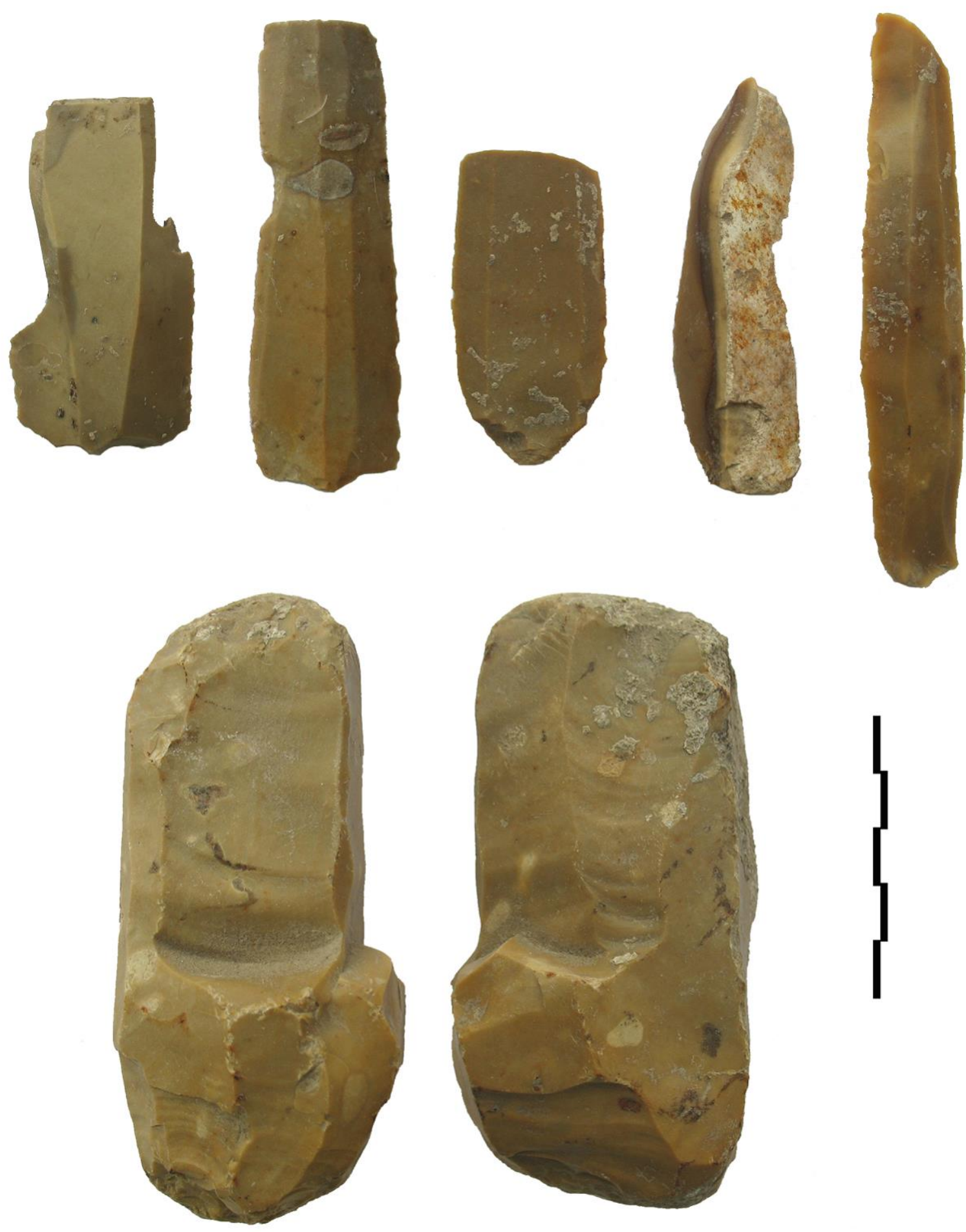

Figure 2. Artefacts of Ludogorie flint from the Chalcolithic site of Bazovets (Russe district). Scale bars: 1 partition $=1 \mathrm{~cm}$. (Photos by M. Gurova.) 

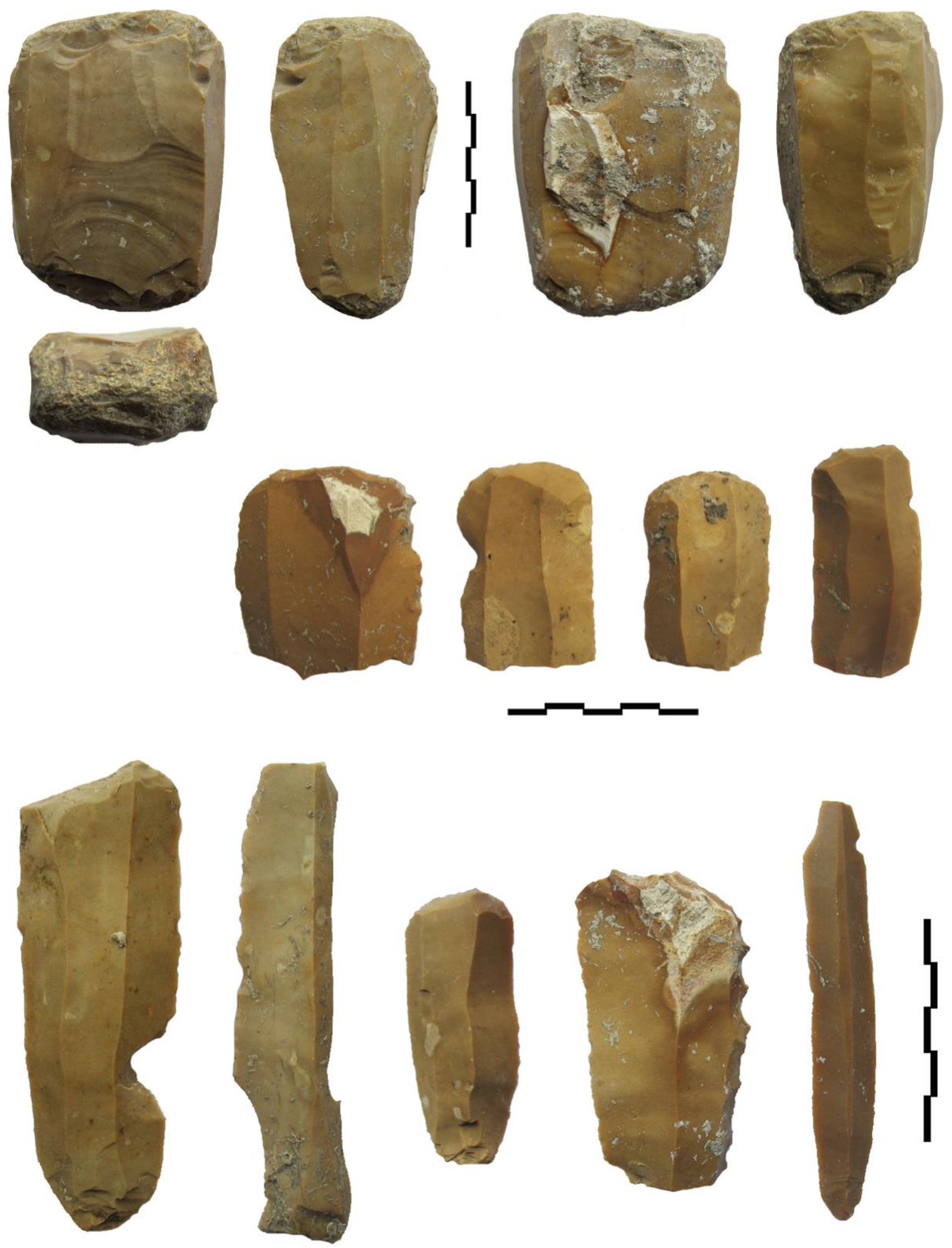

Figure 3. Artefacts of Ludogorie flint from the Chalcolithic site of Kosharna (Russe district). Scale bars: 1 partition $=1 \mathrm{~cm}$. (Photos by M. Gurova.) 

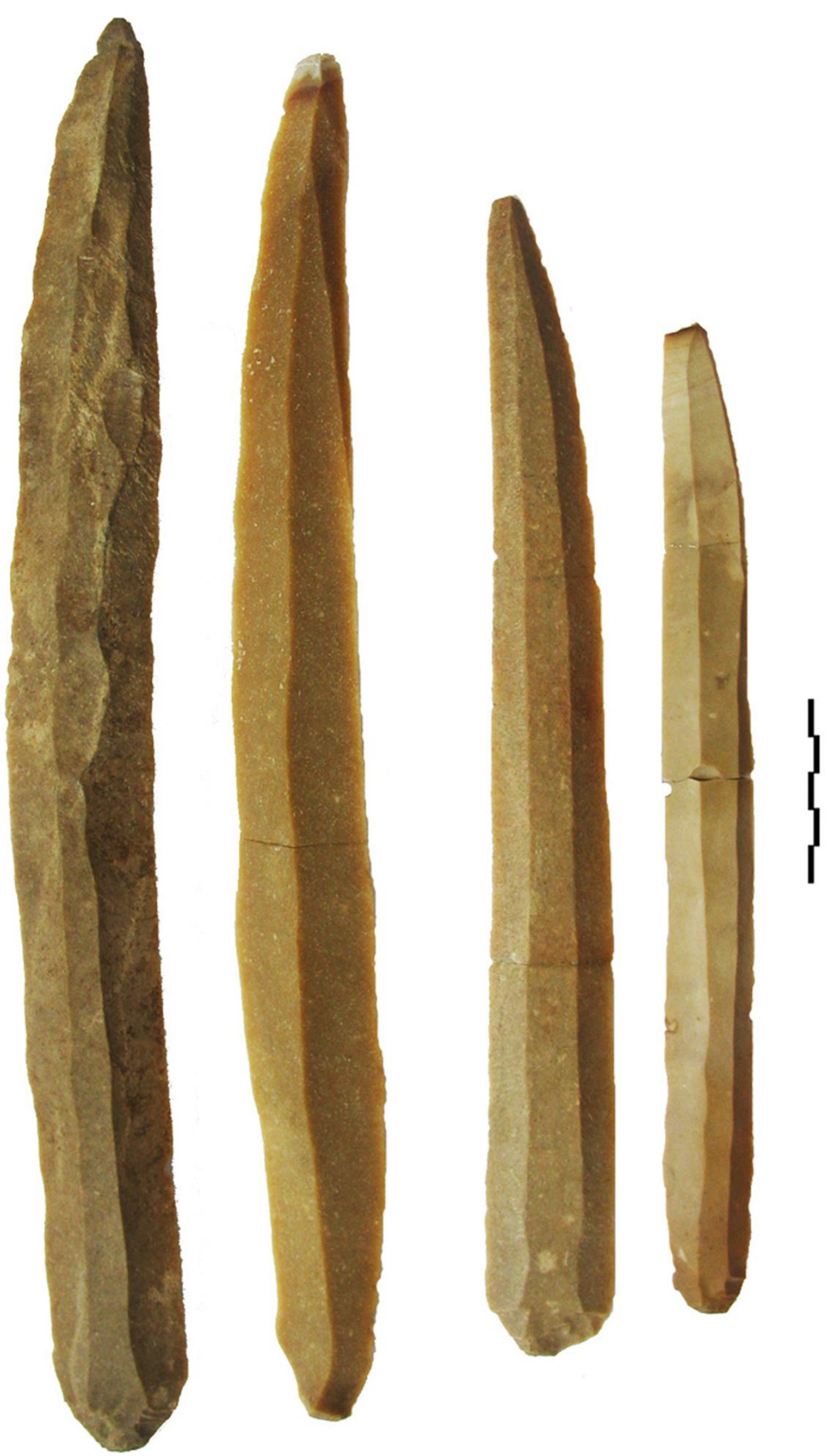

Figure 4. Long and extra-long (superblades) of Ludogorie flint from Varna cemetery (late Chalcolithic Varna culture). Scale bars: 1 partition $=1 \mathrm{~cm}$. (Photo by M. Gurova.) 

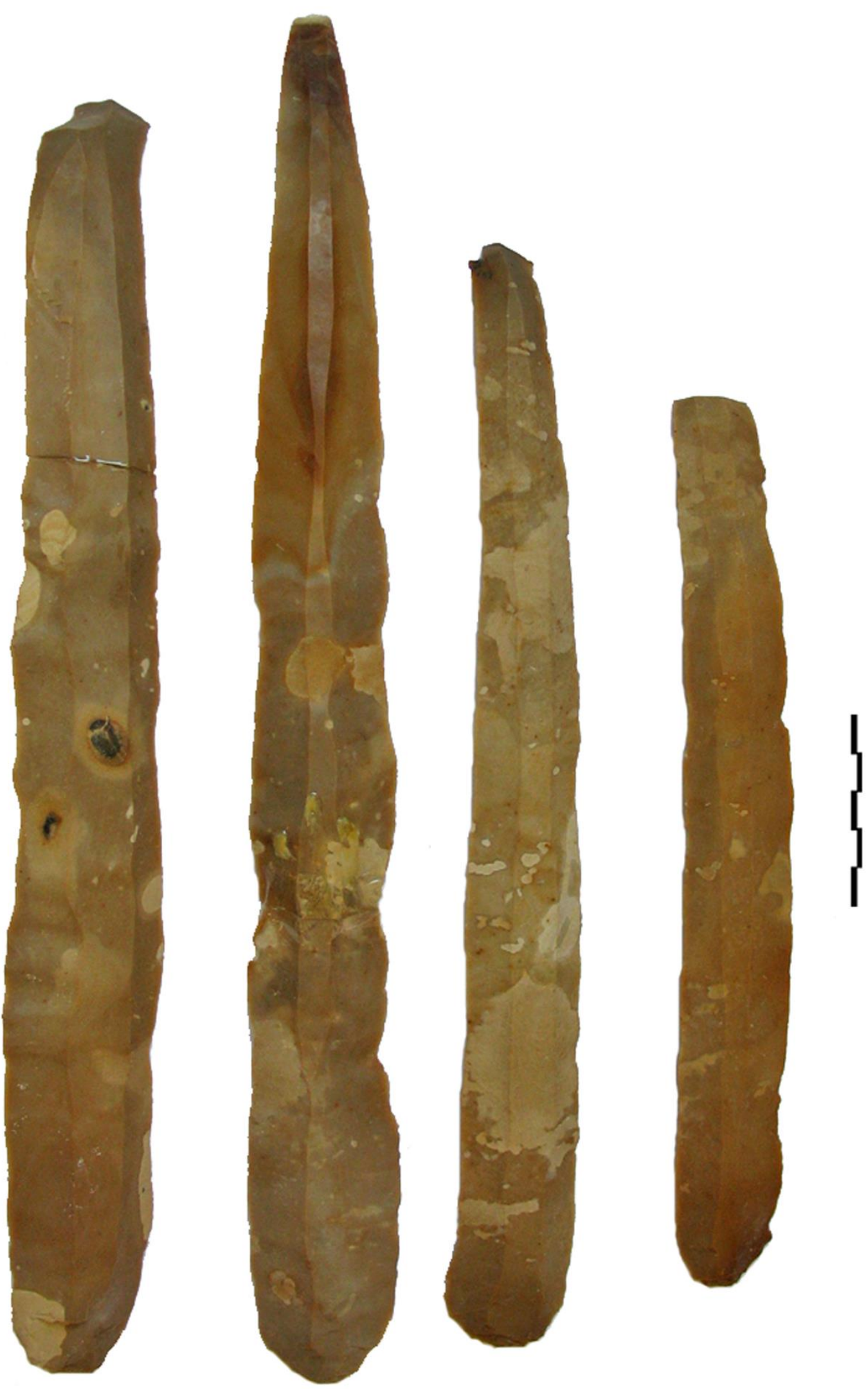

Figure 5. Long and extra-long (superblades) of Ludogorie flint from the Tell Smiadovo hoard I. Scale bars: 1 partition $=1 \mathrm{~cm}$. (Photo by M. Gurova.) 


\subsection{New stage of the investigations of the Ludogorie chert raw material}

The present paper summarizes the results of the survey and subsequent laboratory analysis performed as an extension of a project \{("Prehistoric chert sourcing in NW Bulgaria and NE Serbia: Field survey and laboratory analyses", co-directed by Dr. Dušan Borić (Cardiff University) and Dr. Maria Gurova (NIAM-BAS) \}, focused on northern Bulgarian chert raw materials. Two seasons of surveying in northern Bulgaria were carried out in relation to the project goals: discovering chert deposits, recording them using GPS and marking them on topographic and geological maps; preparing geological descriptions of the raw material deposits; photo documentation of the field conditions, and surface finds; identifying plausible archaeological workshops associated with the chert outcrops; and completing exhaustive collections of raw material samples for archaeometric analyses (thinsection petrographic analyses and LA-ICP-MS ).

The second campaign (in 2012) extended the survey to northeastern Bulgaria Ludogorie region (Russe, Razgrad and Shumen districts) (Figure 6). In this area 15 secondary chert deposits were registered as well as 5 archaeological sites, three of which were already known from the literature and the AMB (Archaeological Map of Bulgaria) system (Gurova et al. $2013 \mathrm{a}-\mathrm{b}$ ). The workshops of prehistoric chert production in Ravno and Kamenovo were documented (Figure 7), as well as the long-lasting tribula insert production center at Kriva Reka village (Figure 8).

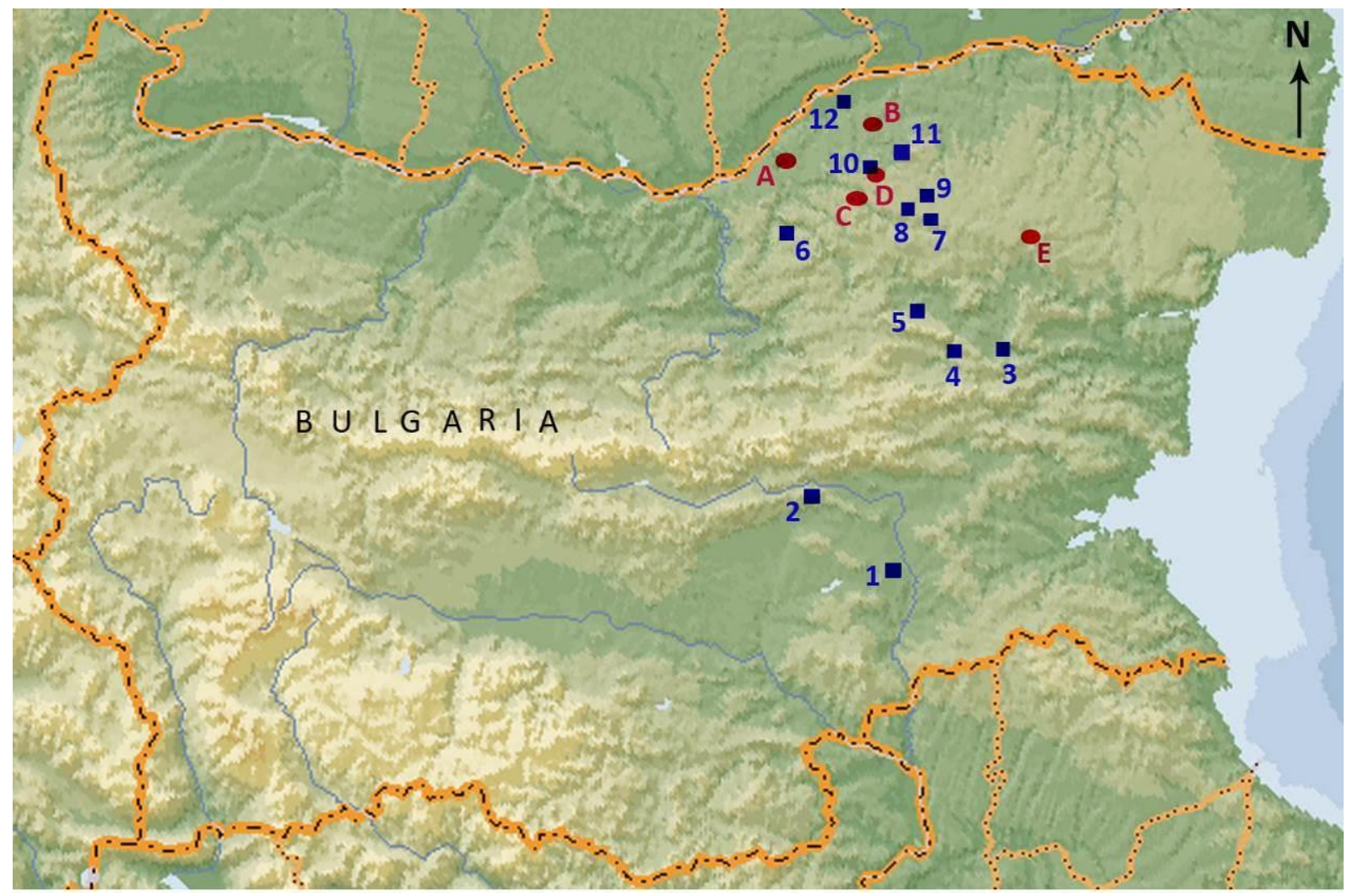

Figure 6. Map of Bulgaria showing the locations where geological (with letters) and archaeological (with numbers) samples mentioned in the article were collected. Geological sites : A. Krasen; B. Tetovo ; C. Krivnia; D. Ravno; E. Kriva Reka. Archaeological sites: 1. Drama-Merdzhumekja; 2. Karanovo; 3. Smiadovo; 4. Ivanovo; 5. Targovishte-Garata; 6. Bazovets; 7. Radingrad; 8. Nedoklan; 9. Golaim Porovets; 10. Ravno; 11. Kamenovo; 12. Kosharna (Created by M. Gurova.) 

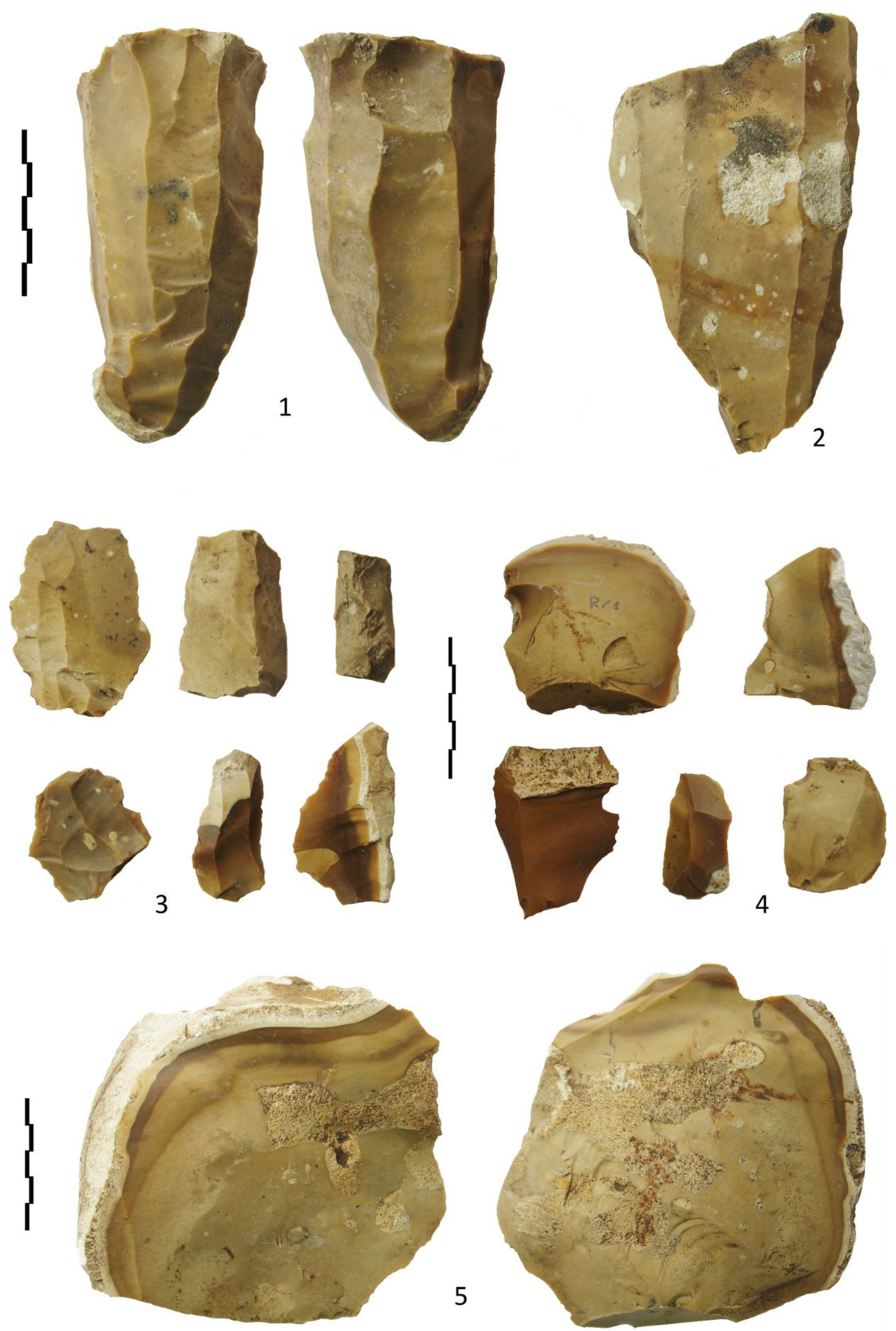
Figure 7. Archaeological evidence (cores and debitage) of a flint workshop at the site of Kamenovo (1. to 3.) and Ravno (4. to 5.) with secondary deposits of flint concretions - Ludogorie flint (Lower Cretaceous). Scale bars: 1 partition $=1 \mathrm{~cm}$. (Photos by M. Gurova.)

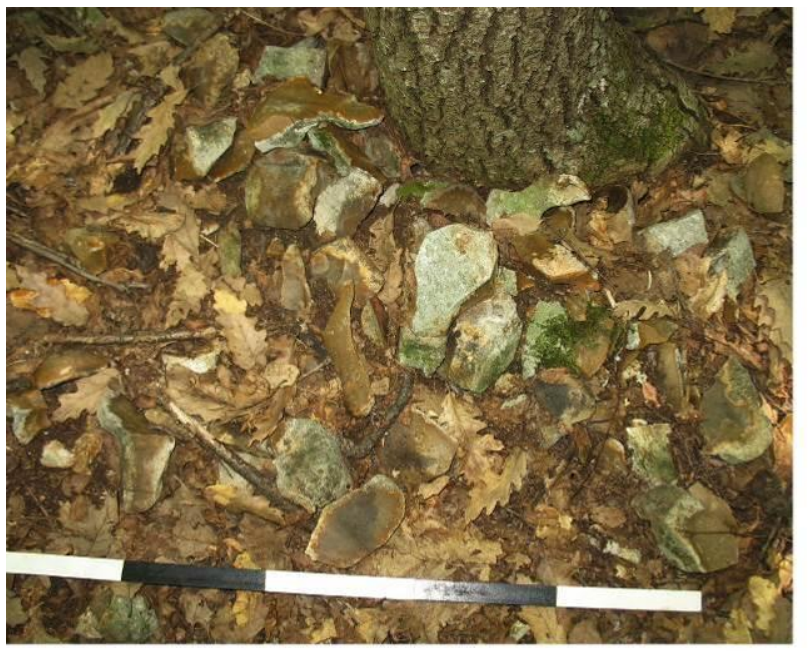

1
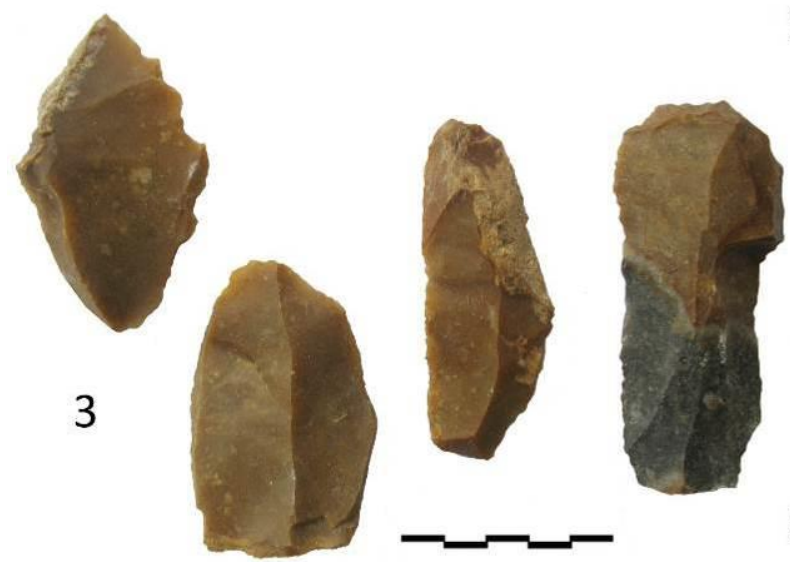

\section{5}

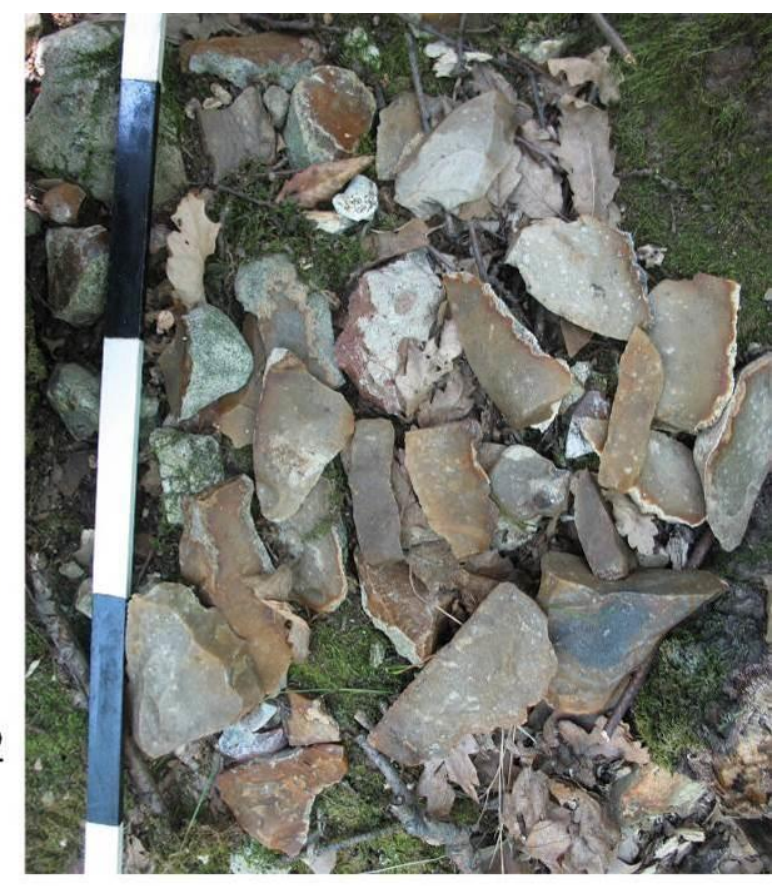

4

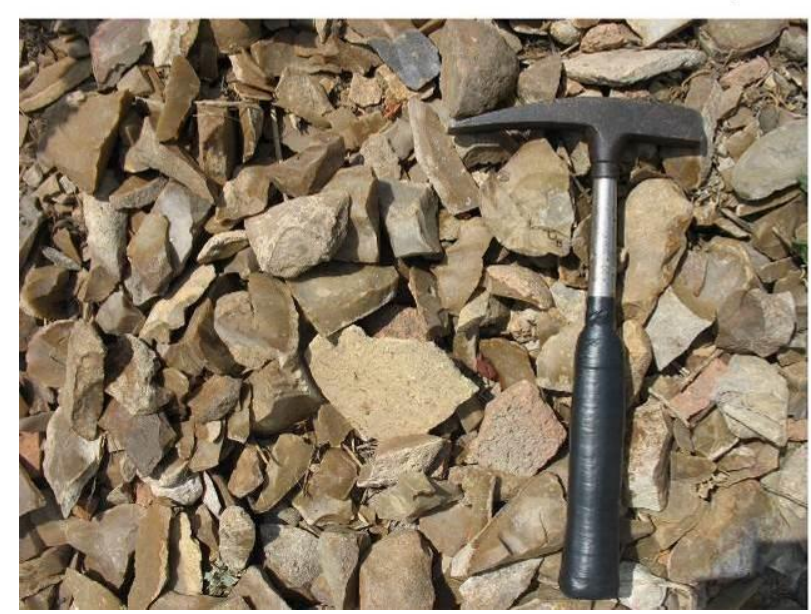

Figure 8. Kriva Reka flint workshop: 1. and 2. cores and debitage at the secondary deposits on Chakmaklaka Hill (scale bars, 1 partition $=10 \mathrm{~cm}$ ); 3. and 4. artefacts and debris from knapping activity in the village of Kriva Reka; 5. one of the few remaining witnesses of the tribulum insert production which took place until the 1950s of the 20th century. Scale bars: 1 partition $=1 \mathrm{~cm}$. (Photos by M. Gurova.) 


\section{Material and Methods}

In the present study we combined two analytical methods (petrographic observation and laser ablation inductively coupled plasma mass spectrometry) to characterize chert artefacts and raw materials from northeastern Bulgaria. Field work was performed in the districts of Russe, Razgrad and Shumen in order to collect Lower Cretaceous (Aptian) raw materials from various chert deposits.

Artefacts from the following Chalcolithic settlements in Bulgaria were analysed: Tell Karanovo and Tell Drama-Merdzumekja (Thracian plain); as well as Smiadovo, Ivanovo, Kosharna, Bazovets, Targovishte-Garata, Radingrad, Nedoklan, Ravno, Kamenovo and Goliam Porovets - all in the northeastern part of the country (Figure 9). The archaeological samples taken are very informative and significant from a raw material point of view (visually representing the main variants of Ludogorie chert). They are also important as being among the most frequently attested and diagnostic typological tools within the assemblages.

All chert samples were macroscopically described (colour, size, shape, texture, cortex, etc.). Thirty-four standard thin sections were also prepared from part of the chert raw material samples and artefacts and were examined under a petrographic microscope. The aim of this study was to describe microscopic chert characteristics (mineralogy, rock texture, limestone relics and fossil assemblages, relative proportion of siliceous and carbonate components, etc.) in an attempt to distinguish petrographically the various chert types.

Based on the macroscopic description and petrographic observations, 31 representative chert samples (raw materials and artefacts) were selected to be analysed by LA-ICP-MS analyses in order to determine their chemistry. Twelve raw materials and 19 artefacts were analysed. At least three analyses per sample were performed. If a chert sample had differently coloured parts, each part was analysed individually.

The LA-ICP-MS system used for analyses consists of a $193 \mathrm{~nm}$ ArF excimer laser coupled with a PE ELAN DRC-e ICP quadrupole mass spectrometer at the Geological Institute of the Bulgarian Academy of Science in Sofia, Bulgaria. For controlled ablation of the material, an energy density of about $10 \mathrm{~J} / \mathrm{cm} 2$ on the sample surface and a laser pulse frequency of $10 \mathrm{~Hz}$ were used. Analyses were performed with a $75 \mu \mathrm{m}$ beam diameter. External standardization by NIST 610 SRM glass provided relative element concentration ratios that were transformed into absolute concentrations by internal standardization. SiO2 content (99 wt.\%) was used as an internal standard, applying the SILLS software (Guillong et al., 2008) for data reduction. In total 45 elements were measured.

\section{Results}

In northeastern Bulgaria the chert raw material occurs predominantly in secondary eluvium (Figure $10 \mathrm{a}-\mathrm{e}$ ), diluvium and (paleo)alluvial (Figure $10 \mathrm{f}-\mathrm{h}$ ) deposits. As mentioned above this chert is known as Dobrudzha or Ludogorie chert (Nachev 2009) and is characterized by Early Cretaceous (Aptian) age (Nachev, Kanchev 1984). Primary deposits are only sporadically present in the Aptian limestone sequence of the Kovachevo Formation (Nikolov 1969), where the chert occurs as layers and beds of variable thickness. 

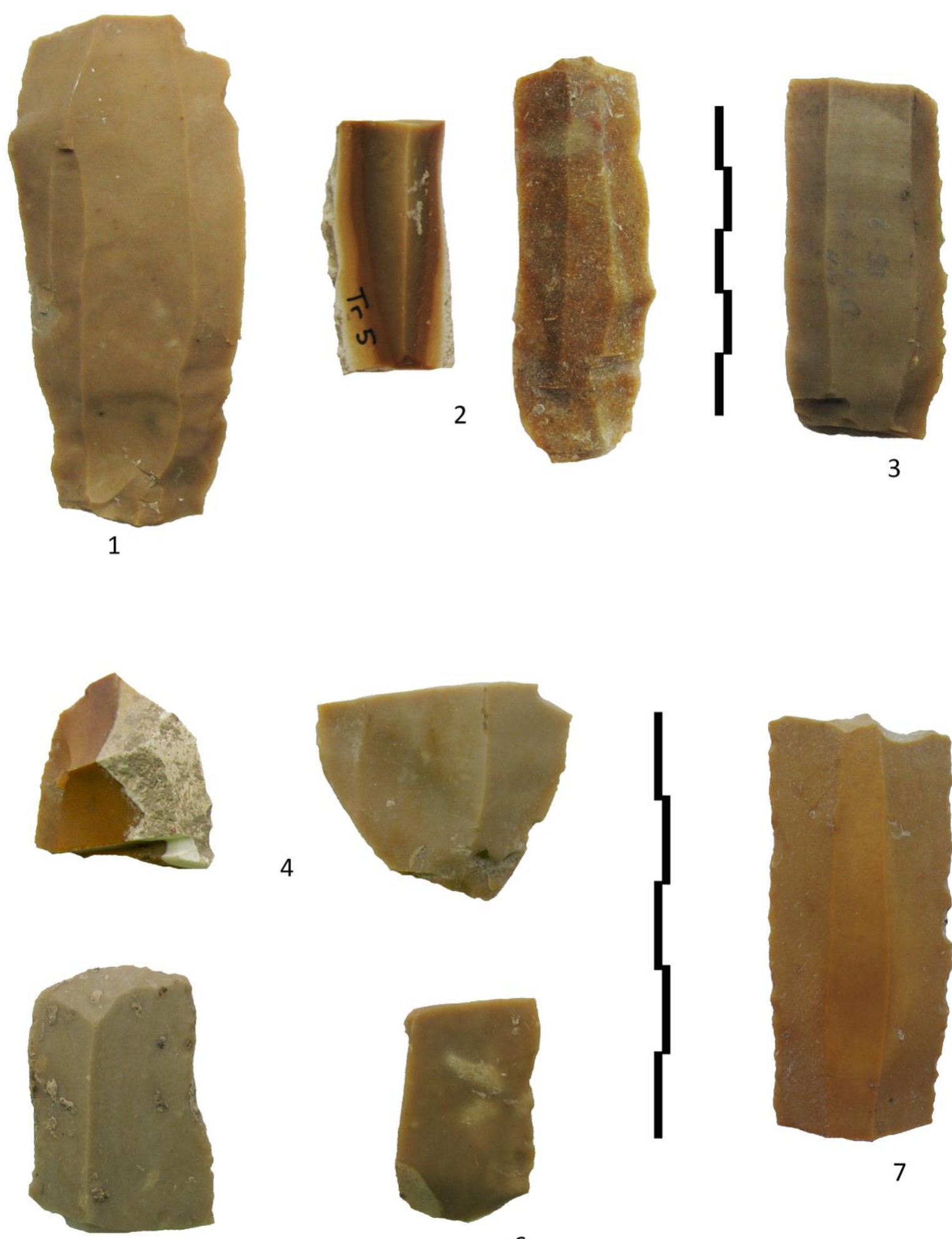

5
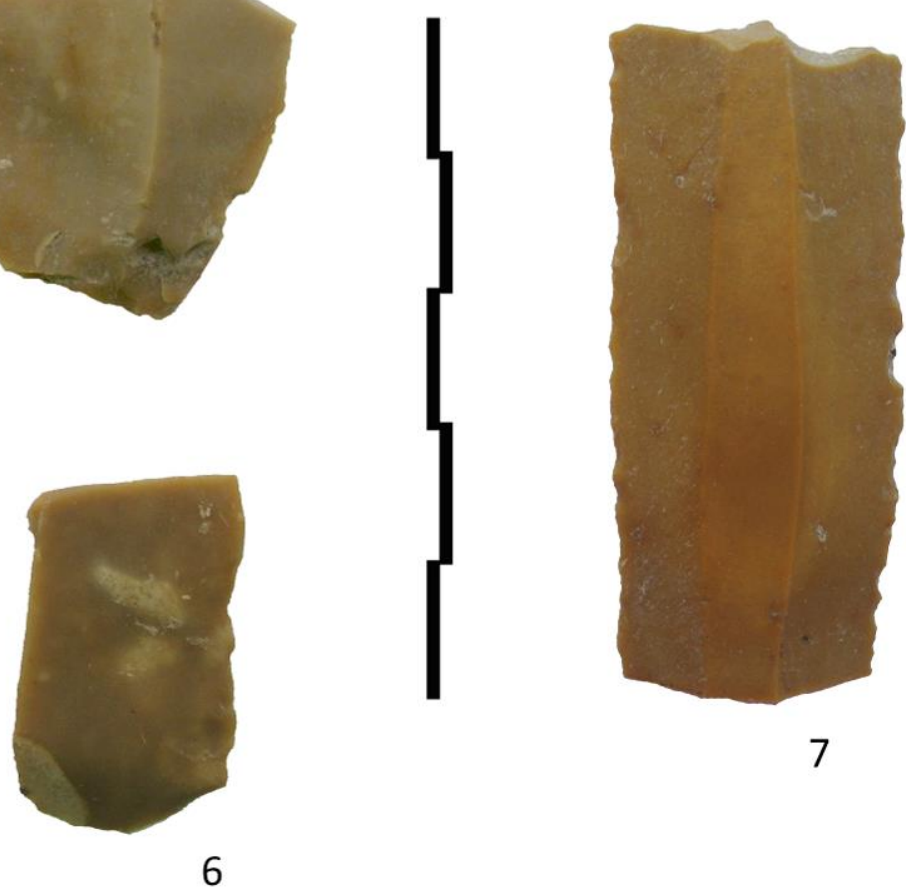

Figure 9. Archaeological samples from Chalcolithic sites in Bulgaria submitted to LA-ICP-MS and thin-section petrographic analysis. 1. Smiadovo; 2. Targovishte (Garata); 3. Goliam Porovets; 4. Bazovets; 5 . Kosharna; 6. Ivanovo; 7. Karanovo. Scale bars: 1 partition $=1 \mathrm{~cm}$. (Photo by M. Gurova.) 

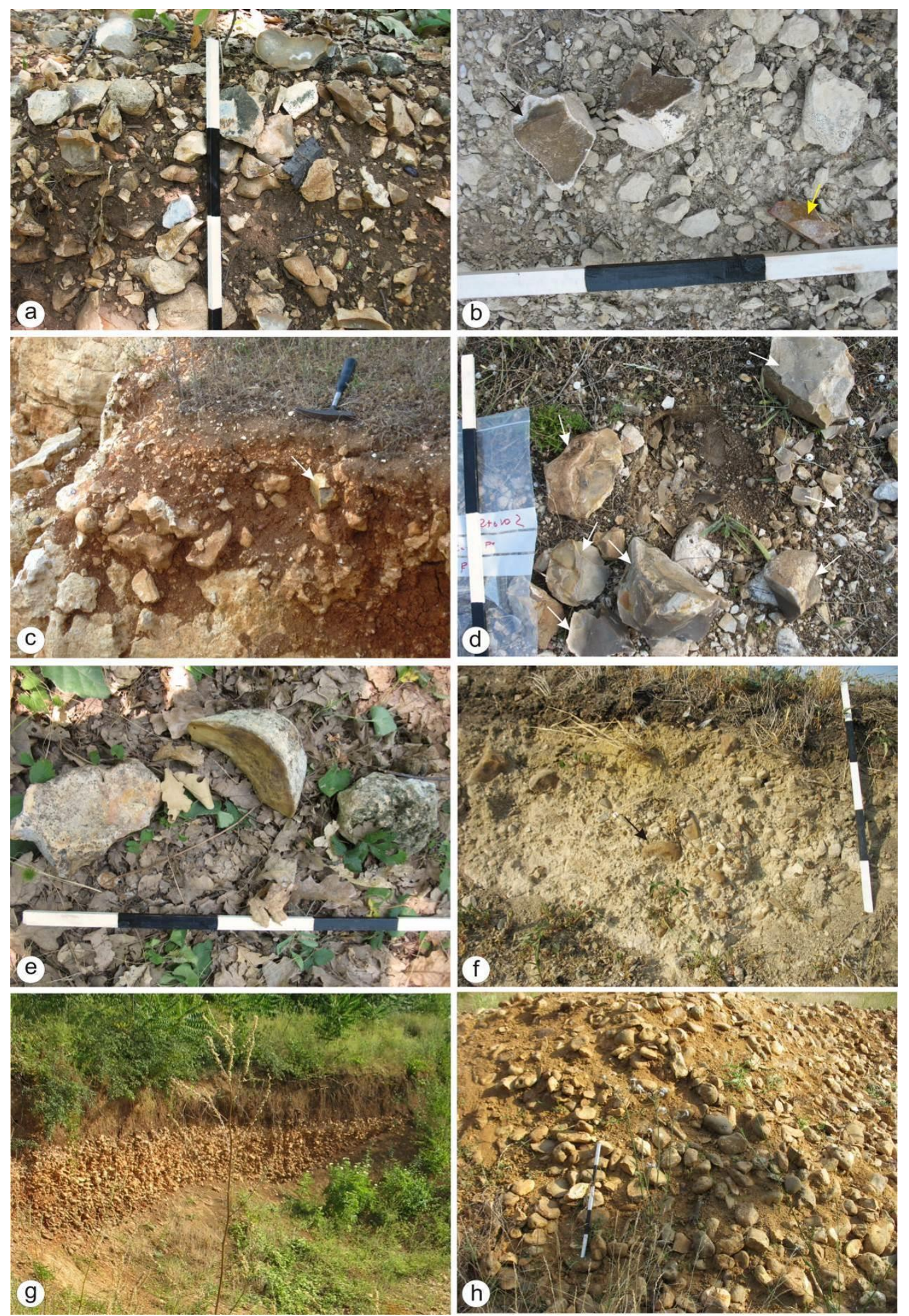

Figure 10. a) Eluvium deposits with flint pebbles and cobbles (Kriva Reka village, Shumen district); b) Flint cobble (black arrows) and artefact (yellow arrow) (Kriva Reka village, Shumen district); c) and d) Eluvium deposits with flint pebbles and cobbles (white arrows) (quarry near Tetovo village, Ruse district); e) Eluvium deposits containing flint cobbles (Ravno village, Razgrad district); f) Palaeoalluvial deposits containing flint pebbles (black arrows) (quarry in Krasen village, Ruse district); g) and h) Palaeoalluvial deposits composed almost completely of flint pebbles and cobbles (Krivnia village, Ruse district). Scale bars: 1 partition $=10 \mathrm{~cm}$. (Created by P. Andreeva.) 


\subsection{Petrography}

On the basis of micropetrographic observations, Gurova and Nachev (2008) described two main chert types (Ravno type and Kriva Reka type). The petrographic observations of the current study confirmed the previous results and distinguished an additional chert type. In this study, the sampled chert raw material from northeasternBulgaria originated mostly from secondary deposits. The latter occur near Ravno village (Razgrad district), in quarries in Tetovo, Krivnya and Krasen (Ruse district) and Kriva Reka (Shumen district). Primary chert deposits, although not suitable for tool preparations, occur only within the limestone sequence of the Kovachevo Formation, which outcrops near to towns Byala and Popovo.

Three main chert types are distinguished on the basis of the macroscopic and microscopic features observed. Type I (Figure $11 \mathrm{a}-\mathrm{d}$ ) is characterized by a great variety of colours (mostly beige, ochre, light brown and dark brown, but light gray, creamy gray, dark gray, purple, and white also occur). The chert texture is homogeneous or sometimes zonal. This chert type is mainly oval shaped and is often distinguished by white cortex. It reaches up to $70 \mathrm{~cm}$ in size (mostly being between 10 and $30 \mathrm{~cm}$ ). Microscopically, the chert is composed of microcrystalline quartz groundmass containing siliceous (chalcedonic) sponge spicules (Figure $11 \mathrm{e}, \mathrm{f}$ ) and sporadic foraminifer tests, thin-shelled bivalves and ostracods replaced by silica minerals. Carbonate components and silt-sized clastic quartz grains are occasionally present in a few samples. The microcrystalline groundmass commonly contains abundant opaque minerals. Most likely, the replaced carbonate rocks were spiculite mudstones and wackestones. This chert variety is known as Ravno type (Gurova and Nachev, 2008 ) and is recognized in the raw materials studied in thin-section from Ravno and Tetovo and artefacts from Ravno, Kamenovo, Goliam Porovets, Radingrad (2) Ivanovo, Kosharna, Bazovets, Targovishte (2) and Smiadovo.

Type II consists of chert pebbles and cobbles between 5 and $15 \mathrm{~cm}$ in size. It is ochre, brown, beige or occasionally gray colour, commonly has white spots and has a white or ochre and brown (within the paleoalluvial deposits) cortex of variable thickness (Figure $11 \mathrm{~g}, \mathrm{~h}$ ). The colour of the cortex is a result of oxidation processes (Figure $11 \mathrm{~h}$, Figure $12 \mathrm{a}$ ). Under the microscope, the material consists of microcrystalline quartz and chalcedony groundmass containing common silicified skeletal grains (crinoids, foraminifers, bryozoans, brachiopods, etc.) and a variable amount (5-15\%) of sand-sized clastic quartz grains (Figure 12 b-d). Siliceous sponge spicules are also presented. Relict carbonate components (5-15\% of the rock volume) include bioclasts (Figure $12 \mathrm{e}$ ) and rare peloids and intraclasts. Most of them are strongly replaced by opaque minerals. Finely-crystalline quartz composed of polygonal crystals is alsoobserved (Figure $12 \mathrm{c}$ ). The replaced carbonate rocks were most likely bioclastic packstones or grainstones. This type is described by Gurova and Nachev (2008) as Kriva Reka type and is represented in the studied thin-sections from raw material in Kriva Reka, Krivnia, and Krasen as well as the artefacts from Kriva Reka, Nedoklan, Radingrad (1), Drama, Karanovo, Targovishte (1).

Type III has a dark brown to dark gray colour (Figure $12 \mathrm{f}$ ) and is represented by silicified limestones (possibly bioclastic-peloidal packstones or grainstones) (Figure $12 \mathrm{~g}, \mathrm{~h}$ ). Silica components are composed of siliceous sponge spicules and chalcedonic groundmass. This chert occurs as separate layers within the limestone succession of the Kovachevo Formation (for example, at Koprivets quarry) or is represented as redeposited pebbles and cobbles in a secondary deposit in the quarry near Krasen village. 

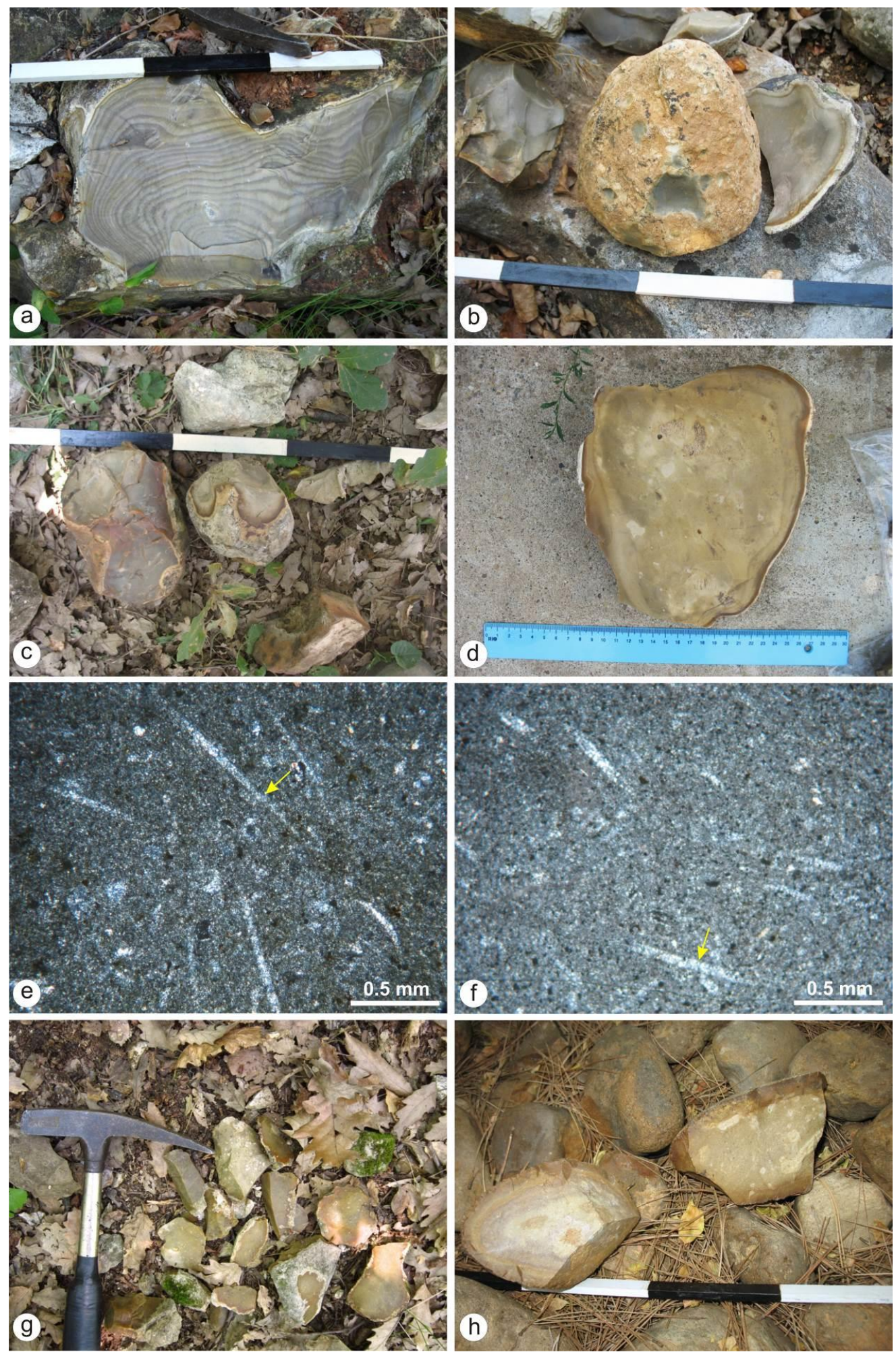

Figure 11 a) Large flint boulder with zonal texture (secondary deposit, quarry near Tetovo village, Ruse district); b) Flint cobbles with oval shapes and white cortexes (secondary deposits, quarry near Tetovo village, Ruse district); c) and d) Flint cobbles and boulders with various colours (secondary deposits, Ravno village, Razgrad district); e) Microcrystalline quartz groundmass containing siliceous sponge spicules (yellow arrow) (raw material, secondary deposit), Ravno village, Razgrad district, CPL (cross-polarized light microphotograph); f) Chalcedonic sponge spicules (yellow arrow) within microcrystalline quartz groundmass (artefact, Kamenovo, Razgrad district), CPL; g) Flint with ochre, brown and beige colours and frequent white spots (secondary deposits, Kriva Reka village, Shumen district); h) Flint pebbles with dark brown and ochre coloured surfaces (secondary deposits, quarry near Krivnya village, Ruse district). Scale bars: 1 partition $=10 \mathrm{~cm}$. (Created by P. Andreeva.) 

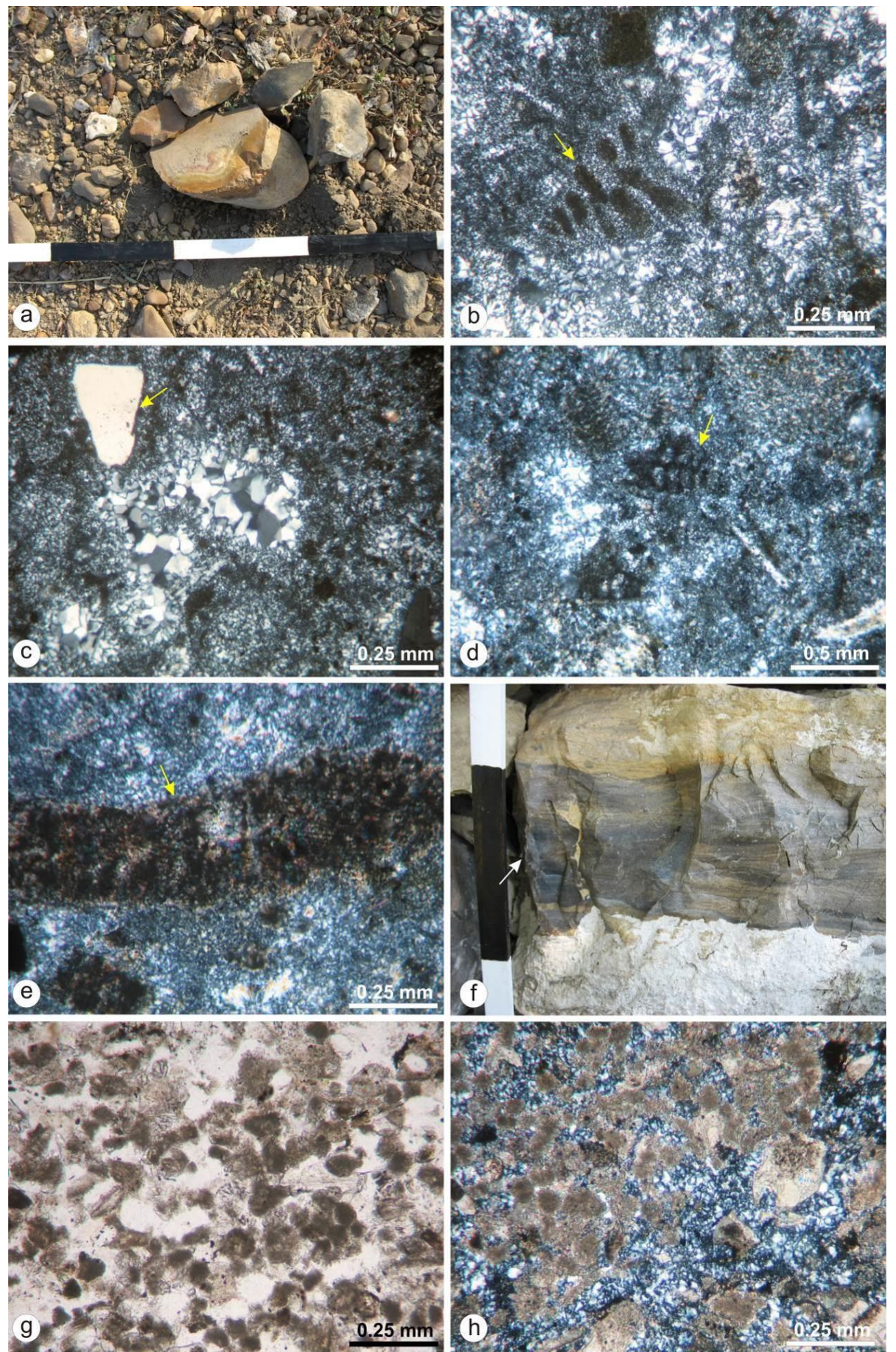

Figure 12 a) Flint pebbles with dark brown and ochre coloured surfaces (secondary deposits, quarry near Krasen village, Ruse district; b) Foraminifer test pseudomorphically replaced by microcrystalline quartz (yellow arrow). Chalcedony which has formed fibrous aggregates (light gray) and locally replaced the previous limestone groundmass (raw material, secondary deposit, Kriva Reka village, Shumen district, CPL); c) Finely-crystalline quartz composed of polygonal crystals, which usually forms mosaics. A clastic quartz grain (yellow arrow) is also observed (raw material, secondary deposit, Kriva Reka village, Shumen district, CPL); d) Pseudomorphically replaced by microcrystalline quartz and opaque minerals foraminifer test (yellow arrow) within quartz and chalcedonic groundmass (artefact, Nedoklan, Razgrad district, CPL); e) Carbonate bioclast (yellow arrow) replaced by opaque minerals (raw material, secondary deposit, Kriva Reka village, Shumen district), CPL; f) Silicified layers (white arrow) in limestones (primary deposits, Kovachevo Formation); g) and h) Bioclastic-peloidal packstones or grainstones (uncertain which) with a rock groundmass replaced by silica minerals (raw material, primary deposits, Kovachevo Formation, quarry near Koprivets village, Ruse district), PPL (plane-polarized light microphotograph) and CPL. Scale bars: 1 partition $=10 \mathrm{~cm}$. (Created by P. Andreeva.) 


\subsection{LA-ICP-MS}

The three petrographically distinguished types of chert artefacts and raw materials from NE Bulgaria (Type I - Ravno type, Type II - Kriva Reka type and Type III - raw materials from quarries near the villages of Koprivets and Krasen) were analysed by LA-ICP-MS. Based on $\mathrm{Al}, \mathrm{Na}, \mathrm{K}$, and $\mathrm{Mg}$ contents, the Ravno type is divided into three subtypes. The first subtype is characterized by low concentrations of the four elements and includes mostly raw materials from the area of Tetovo village and an artefact from Kosharna (2) (Figure 13). The second subtype is represented by raw materials from Ravno village and artefacts from the same area (from Ravno, Kamenovo, Goliam Porovets, Radingrad, Ivanovo, Kosharna (1), Bazovets (2) and Smiadovo) that have average contents of the mentioned elements (Figure 13). The third subtype shows high concentrations of $\mathrm{Al}, \mathrm{Na}, \mathrm{K}$, and $\mathrm{Mg}$ and is represented only by artefacts: from Targovishte (2), Karanovo and Bazovets (1).
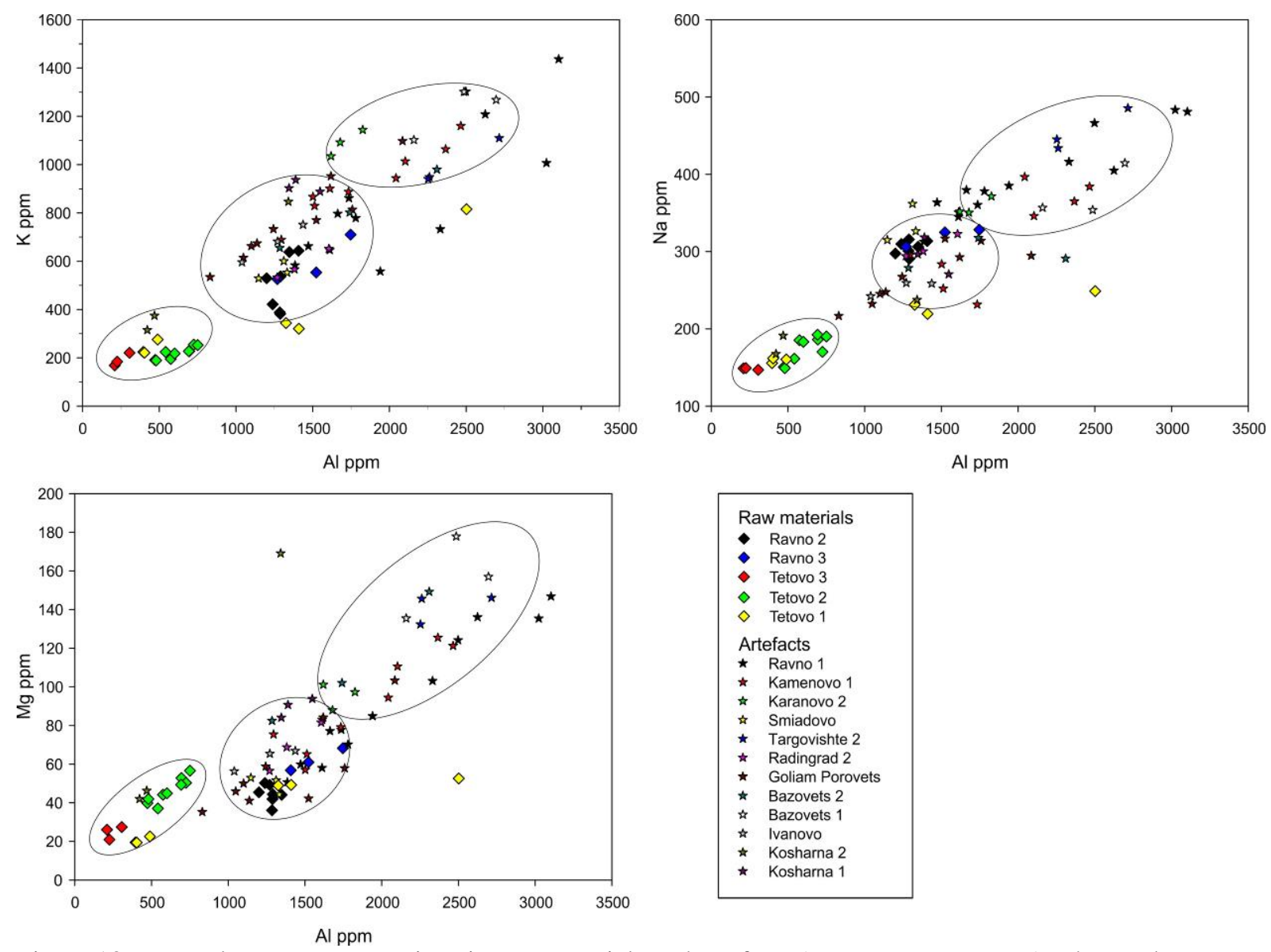

Figure 13. Trace element concentrations in raw materials and artefacts (Type I - Ravno type). Three subtypes are distinguished based on $\mathrm{Al}, \mathrm{K}, \mathrm{Na}, \mathrm{K}$ and $\mathrm{Mg}$ contents. (Created by E. Stefanova.)

The Kriva Reka type has a wide range of these element concentrations due to its inhomogeneous petrographic composition. Nevertheless, the measured values of $\mathrm{Al}, \mathrm{Na}, \mathrm{K}$, and $\mathrm{Mg}$ in raw materials overlap with those observed in artefacts (Figure 14).

The third chert type displays higher $\mathrm{Ca}$ and $\mathrm{Mg}$ concentrations compared to the Ravno and Kriva Reka types (Figure 15). This type is represented only by raw materials. None of the artefacts from Bulgaria which were analysed show such high $\mathrm{Ca}$ and $\mathrm{Mg}$ content. 

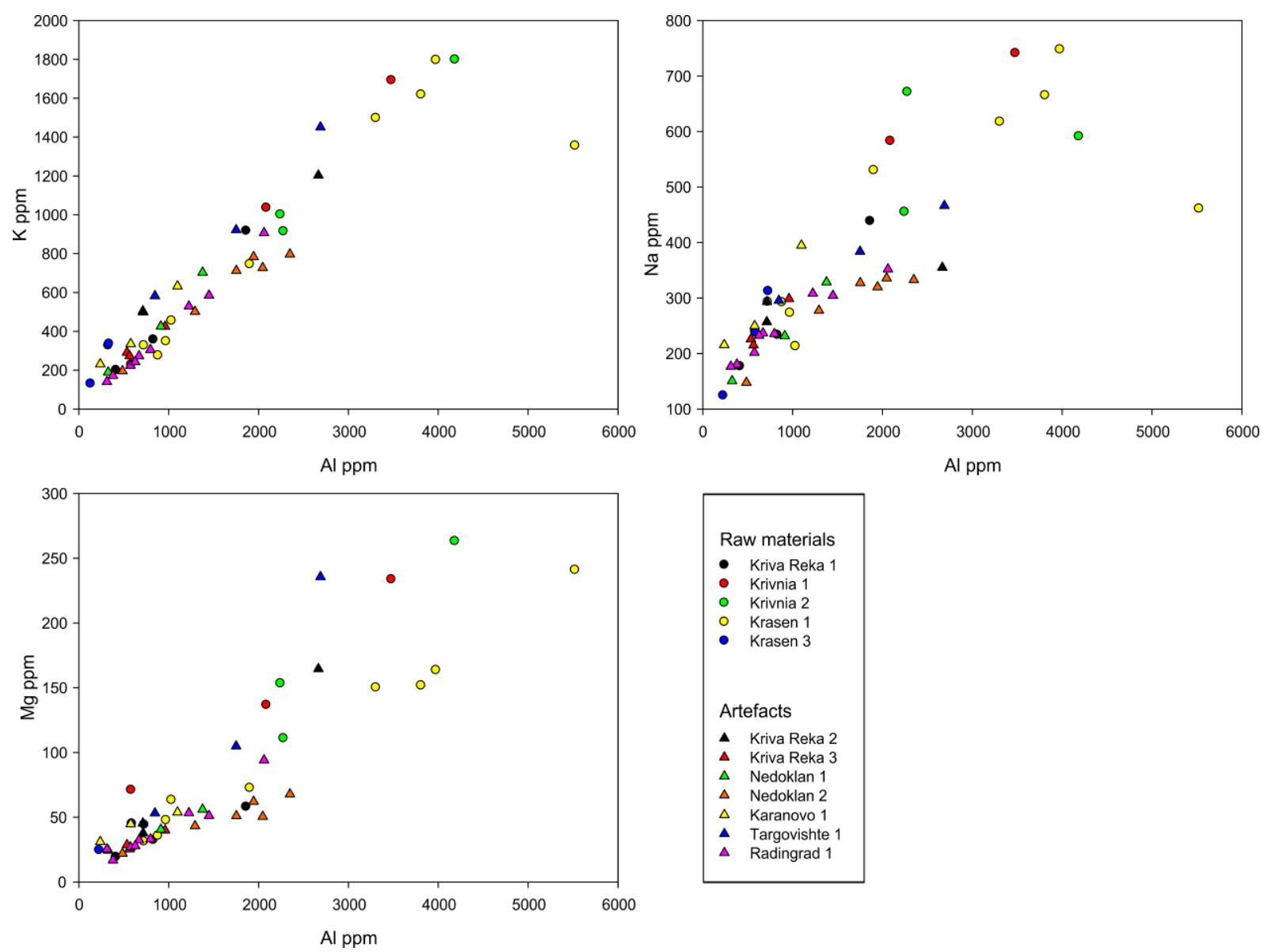

Figure 14. Trace element concentrations in raw materials and artefacts (Type II - Kriva Reka type). Al, K, Na and $\mathrm{Mg}$ contents are scattered and overlap in raw materials and artefacts of this material type. (Created by E. Stefanova.)

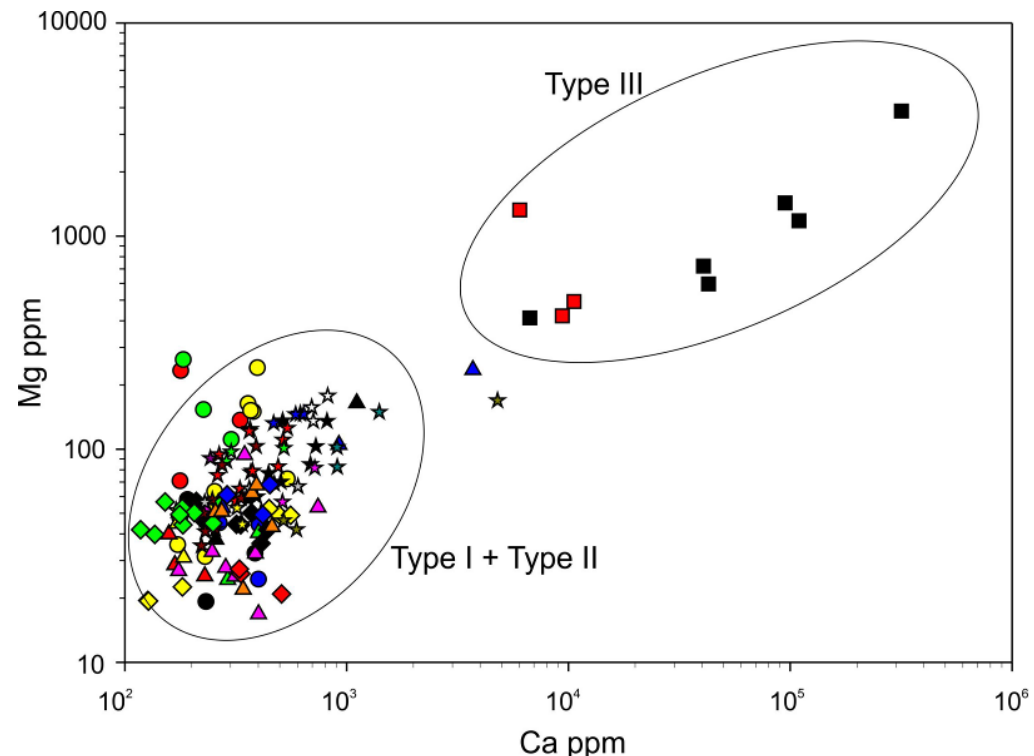

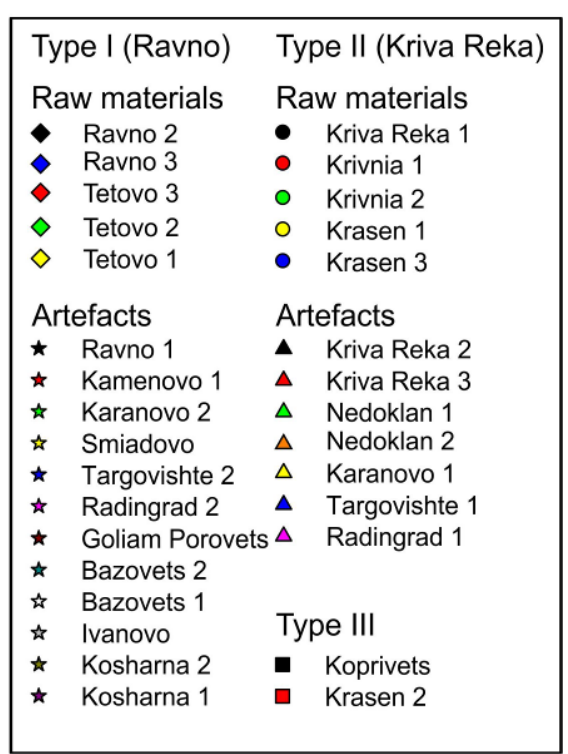

Figure15. Ca versus $\mathrm{Mg}$ plot that distinguishes between type I + II and type III materials. (Created by E. Stefanova.) 


\section{Discussion and Conclusion}

Based on the petrographic study which was carried out, it could be suggested that the possible raw material source for the artefacts from Ravno, Kamenovo, Goliam Porovets, Radingrad (2), Ivanovo, Kosharna, Bazovets, Targovishte (2) and Smiadovo were secondary eluvium chert deposits such as those from near the vilalges of Ravno and Tetovo which were described. All of these cherts are referred to as Ravno chert (Type I). The evidence of this suggestion is the close similarity between the macroscopic and micropetrographic features observed in the raw material and those of the artefacts. The possible raw material source for the artefacts from Kriva Reka, Nedoklan, Radingrad (1), Drama, Karanovo, and Targovishte (1) were presumably secondary eluvium and paleoalluvium deposits such as those recorded near the villages of Kriva Reka, Krivnia, and Krasen. These chert raw materials and artefacts are referred to Kriva Reka chert (Type II).

It is also interesting to note that in some of the archaeological and geological sites which were studied (for example, Radingrad and Targovishte) artefacts from both chert types (Type I - Ravno and Type II - Kriva Reka chert) were distinguished.

A more precise correlation could be made by combination of both petrographic and geochemical data of the raw materials and artefacts studied. Although Ravno (Type I) and Kriva Reka (Type II) chert types are characterized by different petrographic features, we cannot distinguish them based on their chemistry because they have an identical chemical composition. However, several subtypes can be differentiated within the Ravno type (Type I) based on $\mathrm{Al}, \mathrm{Na}, \mathrm{K}$, and $\mathrm{Mg}$ contents. The geochemical data obtained also allowed one to conclude that the possible provenance of the Kosharna (2) artefact was the area of Tetovo village while for the artefacts Ravno, Kamenovo, Goliam Porovets, Radingrad (2), Ivanovo, Kosharna (1), Bazovets (2) and Smiadovo was the area of Ravno village. The overlapping results from the Kriva Reka chert type (Type II) suggest that the raw materials studied could be potential sources for the artefacts from Kriva Reka, Nedoklan, Radingrad (1), Drama, Karanovo, and Targovishte (1). The last chert type (Type III) was not used for tool preparation and is not present among the artefacts which were studied.

\section{Acknowledgements}

The research described in this paper was sponsored by the America for Bulgaria Foundation (Project "Prehistoric chert sourcing in NW Bulgaria and NE Serbia: Field survey and laboratory analyses", coordinated by the American Research Centre in Sofia.

\section{References}

Guillong, M., Meier, D.L., Allan, M.M., Heinrich, C.A. \& Yardley, B.W.D. 2008, Appendix 6: SILLS: a Matlab- based program for the reduction of laser ablation ICP-MS data of homogeneous materials and inclusions. In: Laser Ablation ICP-MS in the Earth Sciences: Current Practices and Outstanding Issues (Sylvester, P., Ed.) Mineralogical Association of Canada Short Course Vol. 40, Mineralogical Association of Canada, Québec: p. 328-333.

Gurova, M. 2005, Feuersteinartefakte. Functionanalyse. In: Karanovo IV : die Ausgrabungen im Nordsüd-Schnitt, 1993-1999. Band IV Band IV (Hiller, S. \& Nikolov, V., Eds.), Phoibos Verlag, Vienna: p. 387-409 \& Pl. 215-220. (in German) ("Chert artefacts. Functional analysis") 
Gurova, M. 2010, Connotations fonctionnelles des grandes lames chalcolithiques : Exemple de la Bulgarie. Archaeologia Bulgarica, 14(2): 1-10. (in French) ("Functional connotation of the Chalcolithic long blade: case study of Bulgaria")

Gurova, M. 2011a, Chalcolithic Flint Assemblages: Trajectory to the Regional Diversity/Similarity. In: Golden Vth millennium. Thrace and neibourhingh regions in the Chalcolithic (Boyadziev, Y. \& Ignatova, S., Eds.), NIAM-BAS, Sofia: p. 273-284.

Gurova, M. 2011b, A Late Chalcolithic Flint Assemblage from the Site of Kosharna, Russe District. In: The Lower Danube in Prehistory: Landscape Changes and HumanEnvironment Interactions (Mills, S. \& Mirea, P., Eds.), Editura Renaissance, Bucharest: p. 179-196.

Gurova, M. 2011c, Етнографски и археологически дикани: трансрегионална перспектива. Bulgarian e-Journal of Archaeology, 1(1): 1-39. (in Bulgarian)

("Ethnographic and archaeological tribula: trans-regional perspective") URL: http://beja.org/article/ethnographic-and-archaeological-tribula-transregional-perspective-2/

Gurova, M., Ivanova, S., Andreeva, P. \& Kiselinov, H. 2013a, Издирвания на археологически обекти в област Русе. In: Археологически открития и разкопки npeз 2012 2. (Archaeological discoveries and excavations in 2012), NIAM-BAS, Sofia: p. 525-527. (in Bulgarian) ("Survey for archaeological settlements in Russe district")

Gurova, M., Ivanova, S., Andreeva, P., Kiselinov, H., Mateva, B. \& Dilov, D. 2013b, Издирвания на археологически обекти в област Разград. In: Археологически открития и разкопки през 2012 2. (Archaeological discoveries and excavations in 2012), NIAM-BAS, Sofia: p. 527-530. (in Bulgarian) ("Survey for archaeological settlements in Razgrad district")

Gurova, M. \& Nachev, C.I. 2008, Formal Early Neolithic flint toolkits: archaeologicaland sedimentological aspects. In: Geoarchaeology and archaeomineralogy. Proceedings of the International Conference, 29-30 October 2008 Sofia (Kostov, R.I., Gaydarska, B. \& Gurova, M., Eds.), “St. Ivan Rilski” Publishing House, Sofia: p. 29-35.

Kanchev, K. 1978, Проучването на флинтовия материал от археологически разкопко. Проблеми и задачи. Интердисииплинарни изследвания (Interdisciplinary Studies), 2: 81-89. (in Bulgarian) ("Investigation of the chert material from the archaeological excavations: problems and purposes")

Manolakakis, L. 2005, Les industries lithiques énéolithiques de Bulgarie. Internationale Archäologie Vol. 88. Verlag Marie Leidorf Rahden, Westphalia, 457 p. (in French) ("The lithic assemblages from the Chalcolithic in Bulgaria")

Manolakakis, L. 2006, Les très grandes lames de Varna : quelle fonction? In: La fin de l'âge de pierre en Europe du Sud: matériaux et productions lithiques taillées remarquables dans le Néolithique et le Chalcolithique du sud de l'Europe : actes de la table ronde de l'EHESS, Carcassonne, 5-6 septembre 2003 (Vaquer, J. \& Briois, F., Eds.) Archives d'Ecologie Prehistorique Vol. 18, Éditions des Archives d'Écologie Préhistorique, Toulouse: p. 5-24. (in French) ("The long blades from Varna (Bulgaria): for which purpose?; In: The end of the Stone Age in southern Europe. Materials and remarkable chipped-stone production in the Neolithic and the Chalcolithic of south Europe")

Manolakakis, L. 2011, A flint deposit, a tell and a shaft: a lithic production complex at Ravno 3-Kamenovo? (Early Chalcolithic, North-East Bulgaria). Studia Praehistorica, 14: 225244. 
Mateva, B. 2011, Exploiting flint deposits in Northeastern Bulgaria in the Chalcolithic. In: The Lower Danube in Prehistory: Landscape Changes and Human-Environment Interactions (Mills, S. \& Mirea, P., Eds.), Renaissance, Bucharest: p. 173-178.

Nachev, C. 2009, Основните типове флинт в България като суровини за направа на артефакти. Интердисциплинарни изследвания (Interdisciplinary Studies), 20-21: 721. (in Bulgarian) ("The main chert types in Bulgaria as raw material for artefacts")

Nachev, I.K. \& Kanchev, K.S. 1984, Aptiean and Quaternary flint in North-East Bulgaria. In: IIIrd Seminar on Petroarchaeology (Plovdiv, 27-30 August, 1984, Bulgaria) (Kunchev, K.S., Nachev, I.K. \& Tcholakov, N.T., Eds.), Institute of Archaeology and Museum Bulgarian Academy of Science, Plovdiv University, Plovdiv: p. 65-82.

Nachev, I.K. \& Nachev, C.I. 1989, Distribution and evolution of siliceous rocks in Bulgaria. In: Siliceous deposits of the Tethys and Pacific Regions (Hein, J.R. \& Obradović, J., Eds.), Springer-Verlag, New York: p. 81-92.

Nikolov, T. 1969, Стратиграфия на долната креда в част от североизточна България. Известия на геологическия институm (Bulletin of Geological Institute, Bulgarian Academy of Sciences), 18: 31-71. (in Bulgarian) ("Stratigraphy of Lower Cretaceous in part of northeastern Bulgaria")

Skakun, N.N. 2006, Орудия труда и хозяйство древнеземледельческих племен Юговосточной Европы в эпоху энеолита (по материалам культуры Варна). Trudy (Institut istorii material'noĭ kul'tury (Rossiǔskaia akademiia nauk)) Vol. 21. НесторИстория, Saint Petersburg, 223 p. (in Russian) ("Tools and economy of the ancient agricultural communities in southeastern Europe in the Chalcolithic (based on the Varna Culture") 